\title{
ROLE OF DEPRESSION IN CHRONIC OBSTRUCTIVE PULMONARY DISEASE PATIENTS
}

Aishwarya Gowda $\mathrm{MB}^{1}$, Sayoojya R Nair ${ }^{1}$, Shefali Deo ${ }^{1}$, Norah H Vanlalhriatmawii ${ }^{1}$, Mohammed Numanuddin ${ }^{2}$ and Khayati Moudgil* ${ }^{1}$ PharmD Intern, Department of Pharmacy Practice, JSS College of Pharmacy Ooty, TamilNadu- 643 001, JSS Academy of Higher Education And Research, Mysuru, INDIA

${ }^{2}$ Clinical Pharmacologist, Breach Candy Hospital, Mumbai, INDIA

\author{
ULOGA DEPRESIJE KOD PACIJENATA SA HRONIČNOM \\ OPSTRUKTIVNOM BOLESTI PLUĆA \\ Aishvaria Govda $\mathrm{MB}^{1}$, Saioojia R Nair ${ }^{1}$, Shefali Deo ${ }^{1}$, Norah H Vanlalhriatmavii', Mohammed Numanuddin² i Khaiati Moudgil* \\ ${ }^{1}$ Odeljenje za farmaceutsku praksu, JSS Farmaceutski koledž Ooti, TamilNadu- 643 001, JSS Akademija za visoko obrazovanje i istraživanje, \\ Misuru, INDIJA \\ ${ }^{2}$ Breach Candi Hospital, Mumbai, INDIJA
}

\begin{abstract}
Chronic obstructive pulmonary disease is a progressive lung disease characterized by chronic obstruction of the lung airflow that interferes with normal bleeding and is not fully reversible. Chronic smoking is the most common risk factor for COPD causing severe cough, wheezing, labored breathing and reduced functionality. COPD not only exerts pulmonary symptoms but also has a spill over the extra pulmonary effects. Owing to the impact of the disease, it may lead to conditions like osteoporosis, cardiovascular complications as well as to psychological effects such as depression and anxiety. Such comorbidities are hidden and are not effectively treated. Depression, one of the most common hidden comorbidities is known to be present but never diagnosed. Various scales like HAM-D and Bode Index can be used to diagnose the extent of depression. Our review mainly focuses on the various studies conducted worldwide and comparing the results of the same. Based on the worldwide analysis, depression is known to affect a COPD patient at later stages and requires immediate diagnosis and appropriate treatment.
\end{abstract} Index.

Keywords: COPD, Cough, Depression, HAM-D, Bode

\section{SAŽETAK}

Hronična opstruktivna bolest pluća je progresivna bolest pluća koju karakteriše hronična opstrukcija protoka vazduha u plućima koja remeti normalno krvarenje i nije u potpunosti reverzibilna. Hronično pušenje je najuobičajeniji faktor rizika za HOBP i prouzrokuje jak kašalj, zviždanje u grudima, otežano disanje i smanjenu funkcionalnost. HOBP ne samo da ispoljava simptome u plućima već dovodi do određenih posledica izvan pluća. Ova bolest može dovesti do stanja poput osteoporoze, kardiovaskularnih komplikacija kao i do psiholoških efekata kao što su depresija i anksioznost. Takvi komorbiditeti su prikriveni i ne leče se efikasno. Za depresiju, jednu od najuobičajenijih prikrivenih komorbiditeta se zna da je prisutna ali nikada dijagnostikovana. Različite skale poput HAM-D i Bod indeksa se mogu koristiti kako bi se dijagnostikovao stepen depresije. Naš rad se uglavnom fokusira na različite studije koje su sprovedene širom sveta i poredjenje rezulata. Zasnovana na svestkoj analizi, za depresiju se zna da utiče na pacijenta sa HOBP u kasnijim stadijumima $i$ zahteva neposrednu dijagnozu i odgovarajuće lečenje.

Ključne reči: HOBP, kašalj, depresija, HAM-D i Bode indeks.

\section{sciendo}

UDK: 616.24-036.1: 616.89-008.454 Ser J Exp Clin Res 2020; 22 (1): 3-9 DOI: $10.2478 /$ sjecr-2020-0028
*Address for Correspondence Clinical Resident Department of Pharmacy Practice, JSS College of Pharmacy Ooty, TamilNadu- 643 001, JSS Academy of Higher Education And Research, Mysuru, INDIA E-mail: khayatimoudgil@jssuni.edu.in 


\section{INTRODUCTION}

Chronic obstructive pulmonary disease (COPD) is a progressive lung disease, which when left untreated can lead to fatal outcomes. COPD commonly manifests as persistent coughing, wheezing, breathlessness and it reduces functional ability. It is estimated that by 2030, COPD will be the third leading cause of death worldwide ${ }^{[1]}$. COPD mainly affects the bronchus and alveoli due to excessive smoking. The epithelial cells are irreversibly damaged due to nicotine dependence. Chronic COPD initially affects only the lungs but if not treated, it can exhibit extra pulmonary effects ${ }^{[2]}$. The predominant ones are cardiovascular abnormalities like Cor Pulmonale, diabetes, weight loss and osteoporosis. Apart from these, there are certain hidden comorbidities which are underdiagnosed and left untreated such as anxiety and depression. There are various scales to diagnose these hidden comorbidities such as HAM-D scale, GDS scale and Bode Index etc. This review mainly focuses on the worldwide studies conducted to assess depression among COPD patients and also attempts to urge the diagnosis and treatment of this comorbidity. Treating depression will not cure COPD, however it will help to cope with the progression of the disease course.

\section{How common is COPD worldwide?}

COPD might not be as common as diabetes mellitus, hypertension or cancer, but as per studies, it is the third leading cause of death and by 2030, it is estimated to affect 6 million people worldwide. Almost every year, various studies are conducted to estimate the burden of the disease. In 2013, one such study estimated that 300 million people were victims of this disease worldwide ${ }^{[3]}$.

As per the Indian epidemiological details as of March 2018, COPD is the second notable cause of death ranging between $2 \%$ to $22 \%$ among men and $1.2 \%$ to $19 \%$ amongst women. COPD ranks $7^{\text {th }}$ among the north eastern states likeManipur, Mizoram, Arunachal Pradesh, Nagaland, Meghalaya, Tripura and Sikkim and $4^{\text {th }}$ among the remaining states of India ${ }^{[4]}$. As per a study conducted by the Indian State-level disease initiative collaborators, the disease transition from 1990 to 2016 was compared. Based on this study, the population of COPD in 1990 and 2016 were compared. COPD crude prevalence had a $29.2 \%$ increase over the years Table 1 which depicts the progressive incidence of the disease. Disease Adjusted Life Years (DALY) along with the total death percentages due to COPD were also estimated and reflected in Table 2.

Chronic Obstructive Pulmonary Disease can affect any adult age group, however, it predominantly occurs over 40 years of age. The 2011-2012 epidemiological data in Europe claimthat the prevalence of COPD in adult population over 40 years falls in the range of $15 \%-20 \%{ }^{[5]}$. The same study also reveals the prevalence to be higher in men than in women, reason being, a high amount of smoking among men. From the past few years, the number of women with COPD is rising quickly than in men as smoking has grown progressively in women too ${ }^{[6]}$. Studies claim a faster decrease in FEV1 values in women with just a few cigarettes than in men. According to the study conducted in a large population, females were observed to have more severe COPD with an early onset (<60yr) and a greater susceptibility to COPD with lower tobacco exposure ${ }^{[7]}$. The prevalence of COPD is considerably higher in smokers than in the non-smoker group, owing to the etiology of the disease. On account of the study conducted in Israel, one fifth of the smokers of the age above 45 years developed COPD ${ }^{[8]}$.

\section{How common is depression in COPD?}

Depression has always been an integral comorbidity of COPD ${ }^{[9]}$. As per a review of various studies, it demonstrates a prevalence of $6 \%-80 \%$ of COPD patients ${ }^{[10,11,12]}$. COPD patients with an underlying comorbid cardiac disease, the chance of depression is between $15 \%-23 \%{ }^{[13,14]}$ and with cancer, it ranges from $13 \%-38 \%{ }^{[15]}$.

\section{Etiology of depression in COPD}

It is commonly believed that the relation is uni-directional i.e. COPD progressively leads to depression. However, it is now postulated that early depression at a young age, urges people towards nicotine dependence, leading to COPD at a later age. The various factors which can lead to depression due to COPD are mainly-

\section{a. Nicotine dependence:}

The mood disorders associated with COPD are largely due to the nicotine dependence ${ }^{[16]}$. The evidence shows that the inflammatory mediators are major contributors in depressive symptoms. A recent study shows that in elderly population the inflammatory biomarkers like interleukin-6 and Creactive protein play a major role in depressive symptoms and pulmonary obstruction ${ }^{[17,18]}$. Another important mechanism of depression and suicidal thoughts is due to the nicotine dependence that shows serotonin and its metabolite levels in the cerebrospinal fluid are lesser than that of a nonsmoker. The prolactin levels in smokers are also seen lesser in response to the serotonin inhibition ${ }^{[19]}$.

\section{b. Genetics:}

A study on blood relatives gives an idea that the first degree relatives of population with major depression are at a higher risk if exposed to smoking. The chances of depression in smokers with the first degree relatives of major depression are 2 to 3\% higher than the non-blood related group. In addition to this statement, the studies on twin and adopted groups prove that the risk of depression in monozygotic twins is high up to of $50 \%$ whereas dizygotic twins are 10 to $25 \%{ }^{[20]}$. 


\section{c. Chronic illness:}

The major contribution of depression in patients with a chronic illness like COPD is due to loss of functionality. The loss of functionality has an attributable risk of $34 \%$ in such patients. The major reasons that lead to depression may be reduced by mobility, inability to perform day to day works and occupational activities ${ }^{[21]}$,that reduces the ability to participate in family and recreational activities that were previously performed. The psychological changes because of these insults may cause depression in the population ${ }^{[22]}$. Studies have shown that patients with chronic illness have less chance for depression when they receive a good social support. Mood disorders, anxiety and depression in patients with chronic illness have less chance to develop if they get a better social support ${ }^{[23]}$

\section{d. Effects of COPD on CNS:}

COPD has a direct relationship on cerebrovascular diseases due to which COPD patients can be a vulnerable population for depression ${ }^{[24]}$. This type of depression is termed as "Vascular Depression". Studies using the Magnetic Resonance Imaging (MRI) show that the development of subcortical hyper intensities (SH) contributes a major role ${ }^{[25]}$. In conclusion, it is mentioned that the patients with hypertension or any coronary artery disease due to COPD are at a higher risk.

\section{Are all COPD patients at a risk of depression?}

A few articles were collected and analyzed regarding this topic. We found out that only one third of COPD patients suffered from depression. All analyzed data have been revealed in Table 3.

Based on all the above studies conducted to assess depression in COPD, it was commonly observed that depression is significantly present as a hidden comorbidity among COPD patients, and frequently used scales are needed to assess depression.

\section{How to diagnose depression in COPD patients?}

Primary health care professionals play an important part in screening and early detection of depression among patients with COPD ${ }^{[26]}$. However, this remains challenging for several reasons: these include the lack of a standardized approach in diagnosis, inadequate knowledge or confidence in assessing the psychological status, as well as the time constraints such as competing agendas, high patient load which leads to less time contact with the patient and the physician. In addition, the system-based barriers such as scarcity of medical records as well as the communication gap between primary health care and mental health care ${ }^{[27]}$. Furthermore, patients are hesitant to reveal the symptoms, owing to the stigma of psychiatric illness. Though there are Biomarker panel available for diagnosing depression, the usage of Structured Interview Method (SDI) questionnaire is standard due to the convenience in administering and quicker result ${ }^{[28]}$. An efficient way to detect the psychological distress is to use reliable, valid and standardized measures of the disease impact, such as questionnaires. The Diagnostic and Statistical Manual (DSM 5) requires at least five or more symptoms to diagnose the patient mainly, anhedonia or depressed mood. Apart from these, somatic and non-somatic symptoms can be considered. The DSM 5 can only classify the patient as depressed or not, however questionnaires like the Hamilton Depression Scale (HAM-D) can classify the severity of depression too ${ }^{[29]}$. The commonly and widely used questionnaire scales include:

- $\quad$ Beck Depression Inventory (BDI)

- $\quad$ Hamilton Depression Scale (HAM-D)

- $\quad$ Hospital Anxiety and Depression scale (HAD)

\section{Hospital Anxiety and Depression Scale (HADS): ${ }^{[30]}$}

The HADS was constructed in 1983 by Zigmond and Snaith. It is a self-administered questionnaire which is used to measure the symptoms of depression and general anxiety in patients of non-psychiatric hospital clinics. 10-15 minutes are required to administer the questionnaire and there are no items regarding somatic symptoms to prevent the overlapping symptoms between the somatic illness and mood disorder. Both inpatient and outpatient can benefit from this scale. Both anxiety (HAD-A) and depression (HAD-D) can be evaluated through 7 items each.

The scores obtained are categorized for both depression and anxiety as follows:

$$
\begin{aligned}
& \text { 0-7 = Normal } \\
& \text { 8-10 = Borderline abnormal (borderline case) } \\
& \text { 11-21 = Abnormal (case) }
\end{aligned}
$$

\section{Beck Depression Inventory (BDI):}

The BDI is 21 items self-administered questionnaire for measuring the severity of depression in normal and psychiatric patients. 10 minutes are required to complete the questionnaire. The highest possible score is $63^{[31]}$.

Based on the score obtained, the score of depression can be interpreted as follows:
$1-10=$ Normal
11-16= Mild mood disturbance
17-20 $=$ Borderline clinical depression
21-30 $=$ Moderate depression
31-40 $=$ Severe Depression
Over $40=$ Extreme depression

\section{Hamilton Depression Rating Scale (HDRS):}

The HDRS also known as the HAM-D scale is a widely used scale for assessment of the severity and change in depression symptoms of depression in elderly patients. There are 17 items $\left(\mathrm{HDRS}_{17)}\right.$ in the original version relating to the 
symptoms of depression experienced over the past week. About 20-30min are required to administer the questionnaire to the subject. The scale emphasizes melancholic and physical symptoms of depression and it is used more commonly in a hospital inpatient. The drawback of the HDRS is that atypical symptoms of depression are not assessed (e.g., hyperphagia, hypersomnia) ${ }^{[32]}$.

The scores can be categorized and interpreted on the following basis:

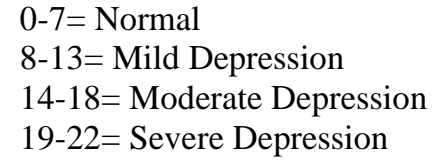

In general, there are different types of scales available to measure the level of depression. But, when it comes to clinical practice, the selection of the scale depends upon the clinician's level of comfort with the scale and availability of time. Some clinicians choose to use the self-rating scales, while other clinicians prefer to ask directly the patients about the symptoms during the visit. Therefore, clinicians play a major role in the selection of the scale depending upon the limitation and strength of a few commonly used scales ${ }^{[33]}$.

\section{MANAGEMENT}

There are no specific treatment guidelines for COPD with comorbid depression. Antidepressants were found to be effective with better quality of life. The treatment depends on the patients who fall in this category of mild, moderate or severe from the results of the scales. The patients are treated accordingly with pharmacological or non-pharmacological treatment.

\section{Pharmacological}

Antidepressants: Antidepressants are commonly used for the treatment of anxiety and depression. According to the study done by AM Yohannes and GS Alexopoulos, these are the drugs used in their study ${ }^{[34]}$.

\section{a) Tricyclic antidepressants (TCA):}

i. Nortriptyline: This drug shows effectiveness in depression, anxiety and other respiratory diseases when compared with placebo. The study used $0.25 \mathrm{mg} / \mathrm{kg}$ of body weight and the weight increased weekly up to $1 \mathrm{mg} / \mathrm{kg}$.

ii. Desipramine: This drug was initiated with a dose of $25 \mathrm{mg}$ and increased weekly to a targeted dose of $100 \mathrm{mg} / \mathrm{kg}$. There was no significant improvement between the placebo and the control group.

iii. Doxepin: This drug was initiated with a dose of $25 \mathrm{mg} / \mathrm{kg}$ till maximum $105 \mathrm{mg} / \mathrm{kg}$ for 6 weeks. But, there was no significant improvement between the two groups. iv. Protriptyline: This drug shows anticholinergic side effects like dryness of mouth; it does not show any clinical improvement given as a dose of $10 \mathrm{mg} /$ day for 12 weeks between the two groups.

\section{b) Selective Serotonin Reuptake inhibitors (SSRIs):}

i. Fluoxetine: It was given as a dose of 20mg daily for 8 weeks. When compared with the placebo and the control group, $67 \%$ had a response to the depressions score scales. But, there was no significant difference between the two groups.

ii. Sertraline: There were no significant improvements in depression patients as well as in COPD patients. A dose of $12.5 \mathrm{mg} / \mathrm{kg}$ was initiated till maximum of $100 \mathrm{mg} / \mathrm{kg}$ for two weeks. But, a retrospective done with a dose of $25 \mathrm{mg}$ to $100 \mathrm{mg}$ in 7 patients with chronic respiratory disease having depression shows an improvement clinically and physically.

iii. Paroxetine: A dose of $20 \mathrm{mg} / \mathrm{kg}$ daily over 12 weeks to the end stage COPD with comorbid depression. Hence, there was a clinical improvement in the controlled when compared with the placebo.

\section{Non-pharmacological}

i. Cognitive-behavioral therapy (CBT): It is a form of psychotherapy used for intervening patients in such a way that will boost their mood, emotional thoughts, resolve problems by encouraging them to challenge distorted cognitions and change destructive patterns of behavior [35]. Anja Fritzsche et al study shows that self-help educational program revealed significant decreases in the Psychosocial and Total Sickness Impact Profile (SIP) scores which indicate improvements in the disease's impact on everyday life and their health status [36].

ii. Pulmonary rehabilitation: According to Kurt B Stage et al, pulmonary rehabilitation has been used for COPD patients for co-morbid depression and anxiety by exercising the patients' breathing related problems and psychological education to help them improve the symptoms and better quality of life.

iii. Singing therapy: A randomized communitybased study done by Hua Liu et al, in China concluded that group singing decreases depression, puts them into a happy mood and it was found to be effective in all patients improving their quality of life [37]. 
Table 1: Change in prevalence of COPD from 1990 to 2016 in Indian population

\begin{tabular}{|c|c|c|c|}
\hline Year & $\mathbf{1 9 9 0}$ & $\mathbf{2 0 1 6}$ & $\begin{array}{c}\text { Percentage change } \\
\mathbf{1 9 9 0 - 2 0 1 6}\end{array}$ \\
\hline India (1316 million) & $3254(3124$ to 3385$)$ & $4204(4032$ to 4378$)$ & $29 \cdot 2 \%(27 \cdot 9$ to $30 \cdot 4)$ \\
\hline
\end{tabular}

Table 2: Percentage of death and DALY due to COPD in India as of 2016

\begin{tabular}{|l|c|c|c|}
\hline \multicolumn{1}{|c|}{ COPD } & Male & Female & Both sexes \\
\hline $\begin{array}{l}\text { Percentage of total deaths in } \\
\text { India 2016 (95\% UI) }\end{array}$ & $8.7 \%$ & $8.6 \%$ & $8.7 \%$ \\
\hline $\begin{array}{l}\text { Percentage of total DALY in } \\
\text { India, 2016 (95\% UI) }\end{array}$ & $5.2 \%$ & $4.4 \%$ & $4.8 \%$ \\
\hline
\end{tabular}

Table 3: Analyzed data from various studies

\begin{tabular}{|c|c|c|c|}
\hline AUTHOR & $\begin{array}{l}\text { SAMPLE } \\
\text { SIZE } \\
\text { (patients) }\end{array}$ & ASSESSMENT TOOLS & OUTCOME/RESULTS \\
\hline $\begin{array}{l}\text { Richard W. Light et } \\
\text { al,1985(10) }\end{array}$ & 45 COPD & Beck depression inventory (BDI) & 19 had significant depression \\
\hline $\begin{array}{l}\text { Mark E. Kunik et al, } \\
\text { 2005(20) }\end{array}$ & 557 COPD & Beck Depression Inventory (BDI) & $\begin{array}{l}\text { Minimal: } 156 \text { patients } \\
\text { Mild: } 121 \text { patients } \\
\text { Moderate: } 147 \text { patients } \\
\text { Severe: } 133 \text { patients }\end{array}$ \\
\hline Sajal De, 2010(21) & 100 COPD & $\begin{array}{l}\text { Patient Health Questionnaire } \\
\text { (PHQ-9) }\end{array}$ & 17 patients with severe depression \\
\hline $\begin{array}{l}\text { Niresh Thapa et al, } \\
\text { 2017(22) }\end{array}$ & 93 COPD & Beck Depression Inventory (BDI) & $\begin{array}{l}\text { Minimal: } 4 \text { patients } \\
\text { Mild: } 14 \text { patients } \\
\text { Moderate: } 41 \text { patients } \\
\text { Severe: } 34 \text { patients }\end{array}$ \\
\hline $\begin{array}{l}\text { Debabani Biswas et al, } \\
\text { 2017(23) }\end{array}$ & 75 COPD & $\begin{array}{l}\text { Hamilton Depression Scale } \\
\text { (HAM-D) }\end{array}$ & $\begin{array}{l}37 \text { patients of COPD with depres- } \\
\text { sion Mild to Moderate: } 37 \text { patients } \\
\text { Severe: } 4 \text { patients }\end{array}$ \\
\hline Ruchi Dua et al, 2018(2) & 128 COPD & $\begin{array}{l}\text { Hospital Anxiety and Depression } \\
\text { scale (HAD) }\end{array}$ & 29 patients with depression \\
\hline $\begin{array}{l}\text { Abhishek Agarwal et al, } \\
\text { 2018(24) }\end{array}$ & 150 COPD & $\begin{array}{l}\text { Hamilton Depression Scale } \\
\text { (HAM-D) }\end{array}$ & $\begin{array}{l}46 \text { patients of COPD with } \\
\text { depression } \\
\text { Mild: } 18 \text { patients } \\
\text { Moderate: } 26 \text { patients } \\
\text { Severe: } 2 \text { patients }\end{array}$ \\
\hline Sujeer Khan, 2017(25) & 120 COPD & Beck’s Depression scale & $\begin{array}{l}\text { Mild: } 6 \text { patients, } \\
\text { Moderate: } 18 \text { patients } \\
\text { Severe: } 42 \text { patients } \\
\end{array}$ \\
\hline Kang Xu, 2018(26) & 53 COPD & $\begin{array}{l}\text { HAM-D/Hamilton Depression } \\
\text { Rating Scale (HDRS) }\end{array}$ & $\begin{array}{l}40 \text { patients with symptoms of } \\
\text { depression }\end{array}$ \\
\hline $\begin{array}{l}\text { Marc Miravitlles et al, } \\
\text { 2018(27) }\end{array}$ & 684 COPD & Beck Depression Inventory (BDI) & $\begin{array}{l}104 \text { patients with severe } \\
\text { depression }\end{array}$ \\
\hline $\begin{array}{l}\text { Josep Montserrat - } \\
\text { Capdevila et al, 2018(28) }\end{array}$ & 512 COPD & $\begin{array}{l}\text { Hospital Anxiety and Depression } \\
\text { scale (HAD) }\end{array}$ & 64 patients with depression \\
\hline Tian Xiao et al, 2018(29) & 275 COPD & $\begin{array}{l}\text { Hospital Anxiety and Depression } \\
\text { Score - Depression (HAD- D) }\end{array}$ & $13.1 \%$ depression \\
\hline
\end{tabular}




\section{CONCLUSION}

This study clearly shows that there exists a link between COPD and depression. So, we have to focus on the comorbidities and their management prior to their severity. More studies should be conducted and the appropriate therapy should be implemented in the future.

\section{ACKNOWLEDGEMENT}

We acknowledge our HOD Dr. S. Ponnusankar for his support and guidance.

\section{CONFLICT OF INTEREST}

We acknowledge our HOD Dr. S. Ponnusankar for his support and guidance.

\section{REFERENCES}

1. WHO | Burden of COPD [Internet]. Who.int. 2019 [cited 18 March 2019]. Available from: https://www.who.int/respiratory/copd/burden/en

2. Dua R, Das A, Kumar A, Kumar S, Mishra M, Sharma K. Association of comorbid anxiety and depression with chronic obstructive pulmonary disease. Lung India. 2018;35(1):31.

3. Tea Vos et al. Global, regional, and national incidence, prevalence, and years lived with disability for 301 acute and chronic diseases and injuries in 188 countries, 19902013: a systematic analysis for the Global Burden of Disease Study 2013. The Lancet. 2015; 386:743-800.

4. Salvi S, Kumar GA, Dhaliwal RS, Paulson K, Agrawal A, Koul PA, Mahesh PA, Nair S, Singh V, Aggarwal AN, Christopher DJ. The burden of chronic respiratory diseases and their heterogeneity across the states of India: the Global Burden of Disease Study 1990-2016. The Lancet Global Health. 2018 Dec 1;6(12): e1363-74.

5. Atsou K, Chouaid C, Hejblum G. Variability of the chronic obstructive pulmonary disease key epidemiological data in Europe: systematic review. BMC Medicine. 2011;9(1).

6. Sorheim I, Johannessen A, Gulsvik A, Bakke P, Silverman E, DeMeo D. Gender differences in COPD: are women more susceptible to smoking effects than men?. Thorax. 2010;65(6):480-485.

7. Barnes P. Sex Differences in Chronic Obstructive Pulmonary Disease Mechanisms. American Journal of Respiratory and Critical Care Medicine. 2016;193(8):813814.

8. Stav D, RazM . Prevalence of chronic obstructive pulmonary disease among smokers aged 45 and up in Israel. Isr Med Assoc J. 2007 ; 9(11) :800-2.

9. Rachel J Norwood. A review of aetiologies of depression in COPD. International Journal of COPD. 2007; 2(4) 485-491
10. Light R, Merrill E, Despars J, Gordon G, Mutalipassi L. Prevalence of Depression and Anxiety in Patients with COPD. Chest. 1985;87(1):35-38.

11. Van Ede L, Yzermans C, Brouwer H. Prevalence of depression in patients with chronic obstructive pulmonary disease: a systematic review. Thorax. 1999;54(8):688692.

12. Yohannes A, Baldwin R, Connolly M. Mood disorders in elderly patients with chronic obstructive pulmonary disease. Reviews in Clinical Gerontology. 2000;10(2):193-202.

13. Carney RM, Freedland KE, Sheline YI, et al. Depression and coronary heart disease: a review for cardiologists. Clin Cardiol. 1997;20(3):196-200.

14. Ariyo AA, Haan M, Tangen CM, et al. Depressive symptoms and risks of coronary heart disease and mortality in elderly Americans. Cardiovascular Health Study Collaborative Research Group. Circulation. 2000; 102(15):1773-9.

15. Kathol RG, Mutgi A, Williams J, et al. Diagnosis of major depression in Cancer patients according to four sets of criteria. Am J Psychiatry.1990;147(8):1021-4.

16. Goodwin RD, Lavoie KL, Lemeshow AR, Jenkins E, Brown ES, Fedoronko DA. Depression, anxiety, and COPD: the unexamined role of nicotine dependence. Nicotine \& tobacco research. 2011;14(2):176-83.

17. Lu Y, Feng L, Feng L, et al. Systemic inflammation, depression and obstructive pulmonary function: a population based study. Respir Res 2013; 14: 53.

18. Yohannes A, Alexopoulos G. Depression and anxiety in patients with COPD. European Respiratory Review. 2014;23(133):345-349.

19. Hughes JR. Smoking and suicide: a brief overview. Drug and alcohol dependence. 2008 Dec 1;98(3):169-78.

20. Mark E Kunik. Surprisingly High Prevalence of Anxiety and Depression in Chronic Breathing Disorders. Chest [Internet]. 2005;127(4):1205-11. Available from: http://dx.doi.org/10.1016/S0012-3692(15)34468-8

21. Sajal De. Prevalence of Depression in Stable Chronic Obstructive. Indian J Chest Dis Allied Sci. 2011; 53:359.

22. Niresh Thapa et al. Anxiety and depression among patients with chronic obstructive pulmonary disease and general population in rural Nepal. BMC Psychiatry. 2017;17(397):1-7.

23. Debabani Biswas et al. Occurrence of Anxiety and Depression among Stable COPD Patients and its Impact on Functional Capability. J Clin Diagnostic Res. 2017;11(2):24-7.

24. Abhishek Agarwal et al. A study on the prevalence of depression and the severity of depression in patients of chronic obstructive pulmonary disease in a semi-urban Indian population. Mondali Arch Chest Dis. 2018;88:54-60.

25. Sujeer Khan et al. Risk of depression in patients with and its determinants. Indian J Heal Sci Biomed Res KLEU. 2017;10:110-5. 
26. Kang Xu. Risk Factors for Depression in Patients with Chronic Obstructive Pulmonary Disease. Med Sci Monit. 2018; 24:1417-23.

27. Marc Miravitlles et al. Depressive status explains a significant amount of the variance in COPD assessment test (CAT) scores. Int J COPD. 2018; 13:823-31.

28. Joseph Montserrat Capdevila et al. Marta Ortega PhD 5. Perspect Psychiatr Care. 2018;1-7.

29. American Psychiatric Association. (2018). Diagnostic and statistical manual of mental disorders (5th ed. update). Arlington, VA: Author.

30. Snaith RP. The hospital anxiety and depression scale. Health and quality of life outcomes. 2003 Dec;1(1):29.

31. Ola Bratas, Kjersti Gronning, Toril Forbord. Psychometric properties of The Hospital Anxiety and Depression Scale and The General Health Questionnaire-20 in COPD inpatients. Scand J Caring Sci; 2014;28:413-420

32. Hamilton M. A rating scale for depression. J Neurol Neurosurg Psychiatry.1960;23:56-62

33. Cusin C, Yang H, Yeung A, Fava M. Rating scales for Depression. In: Handbook of Clinical Rating Scales and Assessment In Psychiatry and Mental Health, Current Clinical Psychiatry. 2009. p.7-35.

34. AM Yohannes and GS Alexopoulos. Pharmacologic Treatment of Depression in Older Patients with COPD : Impact on the course of the disease and health outcomes . Published in final edited form as: Drugs Aging. 2014 July ; 31(7): 483-492.

35. Kurt B Stage, Thomas Middelboe, Tore B Satge, Claus $\mathrm{H}$ Sorensen. Depression in COPD - Management and quality of life considerations. International Journal of COPD 2006:1(3) 315-320

36. Fritzsche A, Clamor A, von Leupoldt A. Effects of medical and psychological treatment of depression in patients with COPD-a review. Respiratory medicine. 2011 Oct 1;105(10):1422-33.

37. Liu H, Song M, Zhai ZH, Shi RJ, Zhou XL. Group singing improves depression and life quality in patients with stable COPD: a randomized community-based trial in China. Quality of Life Research. 2019 Jan 5:1-1. 